\title{
Characteristics of habitats used by a female moose in the managed forest area
}

\author{
Risto HEIKKILÄ, Kaarlo NYGRÉN, Sauli HÄRKÖNEN \\ and Adam MYKKÄNEN
}

\begin{abstract}
Heikkilä R., Nygrén K., Härkönen S. and Mykkänen A. 1996. Characteristics of habitats used by a female moose in the managed forest area. Acta Theriologica 41: 321-326.
\end{abstract}

The use of habitats by one female moose Alces alces (Linnaeus, 1758) in a managed forest area was studied in 1993-1994. The home range area for the whole year 1993 was 4154 ha (the $90 \%$ minimum convex polygon). The area used during January-April in the first winter was 1888 ha ( $71 \%$ of the summer range in May-August). The core area (50\% adaptive kernel) was 408 ha $(9.8 \%$ of home range) in 1993 . Forested peatlands were relatively intensively used by the moose. The old and middle-aged forests were used heavily up until the autumn. In the second winter with thicker snow cover the home range was smaller and the use of available habitats more uniform. The characteristics of stands used in the core area did not differ significantly from the average for the whole area. The availability of food was relatively high even in the old-forest habitats due to the forest edges rich in saplings, particularly in the vicinity of peatland. The moose fed mainly on highly available birch and used more Scots pine in the second winter. The availability of palatable saplings, dwarf shrubs and herbaceous plants appear to have seasonal importance in habitat selection. The tops of recently felled trees were utilized for periods lasting for several days. By combining the basic ecological elements, dynamic factors and effects of browsing, the habitat analyses could probably be useful for management planning in moose areas.

Finnish Forest Research Institute, P.O. Box 18, FIN-01301 Vantaa, Finland (RH, SH); Game and Fisheries Research Institute, FIN-82900 Ilomantsi, Finland (KN); FIN-29200 Harjavalta, Finland (AM)

Key words: Alces alces, home range, habitat selection, landscape ecology

\section{Introduction}

The moose Alces alces (Linnaeus, 1758) is well adapted to use young forest stands, where the effect of forest cover is small (Telfer 1970). The choice of habitats depends on seasonal variation and extremity in climate, as well as on the characteristics of forest stands (Peek et al. 1976). Small-scale forest management improves the quality of moose ranges (Strandgaard 1982). The most extreme changes, such as clearcuttings, have a strong effect on moose habitats (Hamilton 
et al. 1980). According to Van Ballenberghe and Peek (1971), the winter home range consists of a series of high-use areas, whereas the summer range is wider and often includes wetland. The availability of food in young stands (Cederlund and Okarma 1988) and eg willow habitats (Pulliainen et al. 1968, Fedyk et al. 1984, Gębczyńska and Raczyński 1989) can explain the distribution of used habitats. Dryish sites dominated by pine often characterize the winter habitats (Morow 1976, Kuznetsov 1987). In managed forests the environment is expected to change accordingly with areal planning. In the present study the seasonal variation in the characteristics and distribution of the forest habitats used by a female moose are investigated. The habitat and food relationships between forest management and moose behaviour are taken into account by means of classifications of managed forest.

\section{Study area}

The study was conducted in $1993-1994$ in southern Finland $\left(61^{\circ} 15^{\prime}-61^{\circ} 30^{\prime} \mathrm{N}, 22^{\circ} 00^{\prime}-22^{\circ} 30^{\prime} \mathrm{E}\right)$. The study area is mainly lowland with a high percentage of mires drained about $20-30$ years ago. The proportion of forested peatlands is $22 \%$ of the forest area. The fertile sites dominate: the Oxalis-Myrtillus forest type covers 21\% and the Myrtillus type 50\%, whereas the Vaccinium type $7 \%$ of the forest land area (The Forestry Board of Satakunta). Spruce Picea abies is the dominating tree species ( $57 \%$ of the total volume), the proportions of Scots pine Pinus sylvestris and birch Betula pubescens and B. pendula being significantly smaller. The proportions of youngest as well as old stands are relatively small, $5 \%$ and $13 \%$ respectively. The average size of forest compartments in the area is $2-3$ ha.

\section{Methods}

One female moose without calf was radiocollared on January the 7 th, 1993. The locations were determined at least twice a week, mainly in the afternoon in winter and in the evening in summer, when moose are relatively active (Cederlund 1989). Tracking was carried out carefully approaching the animal as close as possible before starting to inspect the stand. A total of 140 observations were made in 1993 (6-18 per month), and 42 in 1994 from January till May (7-10 per month). The coordinates of the locations were mapped. The home range area was defined for different seasons. The CALHOME program (Kie et al. 1994) was used in determining the size of the areas. The $90 \%$ minimum convex polygon method was used for home range and the $50 \%$ adaptive kernel for core area calculations. The intensity of core area use was determined according to Samuel et al. (1985). The forest site types were classified according to plant associations (Cajander 1909). The forest stands were age-classified (Telfer 1984). The expected areal distribution was: young stands (0-20 years) $31 \%$, pole stands (21-40 years) 28\%, middle-aged stands ( $41-80$ years) $28 \%$ and old stands (over 80 years) $13 \%$. The proportions of tree species in the stands were counted on 5-8 randomly located one-acre plots. The food plants (frequently and occasionally utilized) were recorded on 1-3 one-acre plots (91 locations). In statistical analyses the expected and observed proportions were analysed using the $G^{2}$-test and pairwise comparisons by calculating the Bonferroni confidence intervals $(p<0.05)$ for the observed values (Neu et al. 1974, Byers and Steinhorst 1984). The periodical variation was analysed using the Pearson $\chi^{2}$-test (BMDP program). 


\section{Results}

The total area covered by the location points in 1993 was 8754 ha and the $90 \%$ minimum convex polygon home range area 4154 ha (Fig. 1). The respective seasonal values were: winter 2589 ha (1888 ha), summer 5831 ha (2657 ha) and autumn 2038 ha (1017 ha). The area used during January-May in 1994 was 2839 ha (1078 ha). The core area frequently used during different seasons (50\% of all sightings in 1993 and $61 \%$ in 1994) was situated close to a large forested peatland complex and its size was 408 ha (9.8\% of home range). The intensity of the core area use (percent of locations/percent of home range area) was 3.4 in 1993 and 4.1 for the whole study period.

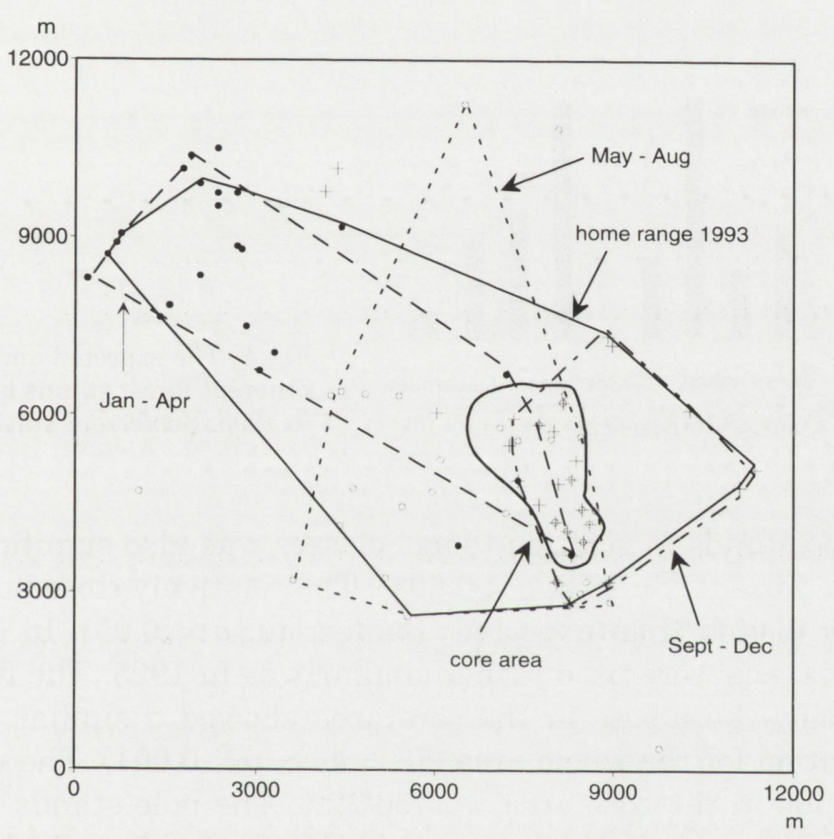

Fig. 1. Home range of the female moose in 1993 (solid line - 90\% convex polygon) and the core area (50\% adaptive kernel). Black circles - January-April, open circles - May-August, + - September-December.

The seasonal distribution of moose locations in forest stands in 1993 is presented in Fig. 2. No sightings were made of open bogs. Spruce forests were typical of the winter and pine-dominated, less closed habitats were more used towards the autumn (Pearson $\chi^{2}=40.362, \mathrm{df}=15, p=0.0004$ ). The year-round use of forest site types in 1993 showed that the forested peatlands were, on the average, most frequented by the moose $\left(G^{2}=39.2, p<0.001\right)$. The mineral soil types were less used and the peatland forests more used than expected (Bonferroni: $p<0.05$ ). The relationship use/availability of peatlands was $49 / 22 \%$. The year- 

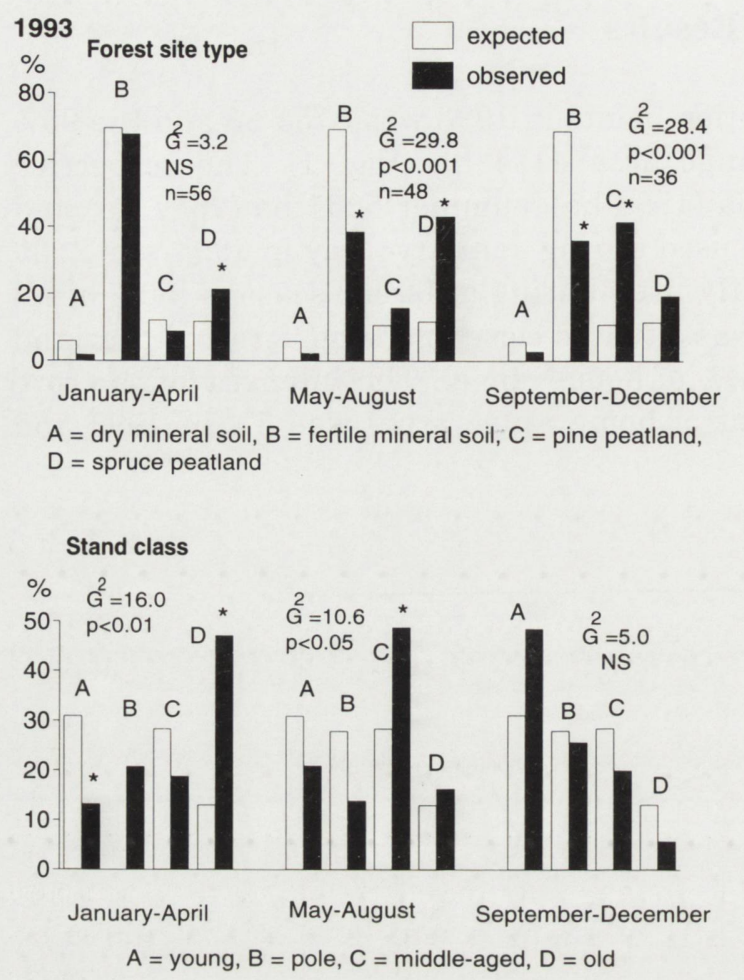

Fig. 2. The expected and observed usage of different forest stands by the female moose in 1993. Bonferroni statistics: ${ }^{*}-p<0.05$.

-round use of the stands in relation to age classes was also significantly different from the expected use $\left(G^{2}=18.2, p<0.001\right)$. The relatively closed old stands were more frequently visited than expected (Bonferroni: $p<0.05$ ). In 1994 January-April the forest types were used rather similarly as in 1993. The forest site types seasonally used by the moose in the core area showed a similar pattern as the average distribution for the whole area $\left(G^{2}=44.8, p<0.001\right)$. The use/availability ratio for peatlands in the core area was $60 / 22 \%$. The pole stands were less used and the old stands more used than expected (Bonferroni: $p<0.05$ ).

The most commonly used plants throughout the year were birch species, of which pubescent birch was freely available. In winter twigs of aspen Populus tremula and willows (especially Salix caprea) were widely used when available. The forest edges rich in deciduous saplings were often the main food source and understory saplings were rather sparsely distributed. Scots pine and juniper Juniperus communis were used more during the second winter when there was a snow cover of $10-30 \mathrm{~cm}$. The moose had been feeding on the tops of recently felled birches for several days during both of the winters. Blueberry Vaccinium myrtillus was commonly used in snowless January 1993 during a two-weeks period. This species was occasionally digged out close to spruces where the snow cover was thin. In late April and May the new growth of cotton grass Eriophorum vaginatum 
was chosen in peatland habitat. Summer feeding was observed on deciduous trees, fireweed Epilobium angustifolium, raspberry Rubus idaeus, blueberry, heather Calluna vulgaris and lingonberry Vaccinium vitis-idaea.

\section{Discussion}

In the present study the seasonal ranges were widely distributed and it was not possible to identify any distinctively separate seasonal home range areas. This is typical of a flat terrain (Van Ballenberghe and Peek 1971, Cederlund and Okarma 1988). The total area of the locations was relatively large even in winter, obviously due to the thin snow cover and good quality of habitats in the small-scale forest mosaic beneficial for selective feeding (Saether et al. 1989). Deciduous understory vegetation and forest edges appeared to be important for moose feeding (Hjeljord et al. 1990, Histoel and Hjeljord 1993). Dwarf shrubs are an important food source (LeResche and Davis 1973) depending on snow cover. The phenological stages of food plants are suggested to affect the activity pattern of moose in spring and autumn (Cederlund 1989). The characteristics of used forests did not differ of the average in the core area highly utilized during both of the winters probably indicating traditional learning (Sweanor and Sandegren 1989, Cederlund and Sand 1992). In the study area drained peatlands are an essential element in a moose habitat obviously due to the overall high food supply and the wetland characteristics in summer (Cederlund et al. 1980). The value of a habitat is evidently improved by the close availability of forest stands with palatable saplings, in our area aspen and willows as understory vegetation or at forest edges in older stands. Logging areas support considerable food resources in winter and their new-growth vegetation evidently improves the food supply for a longer period. It is assumed that the information of the basic ecological elements as well as dynamic factors could be used as components in predicting the most beneficial habitats. Taking into account the effects of consumption and damage on different tree species (Heikkilä and Härkönen 1993), the habitat analyses could be useful when planning forest management in moose areas.

\section{References}

Ballenberghe V. van and Peek J. M. 1971. Radiotelemetry studies of moose in northeastern Minnesota. Journal of Wildlife Management 35: 63-71.

Byers C. R. and Steinhorst R. K. 1984. Clarification of a technique for analysis of utilization-availability data. Journal of Wildlife Management 48: 1050-1053.

Cajander A. K. 1909. Über Waldtypen. Acta Forestalia Fennica 1: 1-175.

Cederlund G. 1989. Activity patterns in moose and roe deer in a north boreal forest. Holarctic Ecology 12: $39-45$. 
Cederlund G., Ljungqvist H., Markgren G. and Stålfelt F. 1980. Foods of moose and roe-deer at Grimsö in Central Sweden - results of rumen content analyses. Swedish Wildlife Research Viltrevy 11: 169-247.

Cederlund G. and Okarma H. 1988. Home range and habitat use of adult female moose. Journal of Wildlife Management 52: 336-343.

Cederlund G. and Sand H. 1992. Dispersal of subadult moose (Alces alces) in a nonmigratory population. Canadian Journal of Zoology 70: 1309-1314.

Fedyk S., Gębczyńska Z., Pucek M., Raczyński J. and Sikorski M. D. 1984. Winter penetration by mammals of different habitats in the Biebrza valley. Acta Theriologica 29: 317-336.

Gębczyńska Z. and Raczyński J. 1989. Distribution, population structure, and social organization of moose in the Biebrza Valley, Poland. Acta Theriologica 34: 195-217.

Hamilton G. D., Drysdale P. D. and Euler D. L. 1980. Moose winter browsing patterns on clear-cuttings in northern Ontario. Canadian Journal of Zoology 58: 1412-1416.

Heikkilä R. and Härkönen S. 1993. Moose (Alces alces L.) browsing in young Scots pine stands in relation to the characteristics of their winter habitats. Silva Fennica 27: 127-143.

Hjeljord O., Hövik N. and Pedersen H. B. 1990. Choice of feeding sites by moose during summer, the influence of forest structure and plant phenology. Holarctic Ecology 13: 281-292.

Histoel T. and Hjeljord O. 1993. Winter feeding strategies of migrating and nonmigrating moose. Canadian Journal of Zoology 71: 1421-1428.

Kie J. G., Baldwin J. A. and Evans C. J. 1994. CALHOME. Home range analysis program. U. S. Forest Service, Fresno, California, USA.

Kuznetsov G. V. 1987. Habitats, movements and interactions of moose with forest vegetation in USSR. Swedish Wildlife Research, Suppl. 1: 201-211.

LeResche R. E. 1974. Moose migrations in North America. Naturaliste Canadien 101: 393-415.

LeResche R. E. and Davis J. L. 1973. Importance of nonbrowse foods to moose on the Kenai peninsula, Alaska. Journal of Wildlife Management 37: 279-287.

Morow K. 1976. Food habits of moose from Augustów Forest. Acta Theriologica 21: 101-116.

Neu C. W., Byers C. R. and Peek J. M. 1974. A technique for analysis of utilization-availability data. Journal of Wildlife Management 38: 541-545.

Peek J. M., Ulrich D. L. and Mackie R. J. 1976. Moose habitat selection and relationships to management in northeastern Minnesota. Wildlife Monographs 48: 1-65.

Pulliainen E., Loisa K. and Pohjalainen T. 1968. Winter food of the moose (Alces alces L.) in eastern Lapland. Silva Fennica 2: 235-247. [In Finnish with English summary]

Saether B. E., Engen S. and Andersen E. 1989. Resource utilization of moose Alces alces during winter. Finnish Game Research 46: 79-86.

Samuel M. D., Pierce D. J. and Garton E. O. 1985. Identifying areas of concentrated use within the home range. Journal of Animal Ecology 54: 711-719.

Strandgaard S. 1982. Factors affecting the moose population in Sweden during the 20th century with special attention to silviculture. Swedish University of Agricultural Sciences, Department of Wildlife Ecology, Report 8: 1-31.

Sweanor P. Y. and Sandegren F. 1989. Winter-range philopatry of seasonally migratory moose. Journal of Applied Ecology 26: 25-33.

Telfer E. S. 1970. Winter habitat selection by moose and white-tailed deer. Journal of Wildlife Management 34: 553-559.

Telfer E. S. 1984. Circumpolar distribution and habitat requirements of moose (Alces alces). [In: Northern ecology and resource management. R. Olson, R. Hastings and F. Geddes, eds]. University of Alberta Press, Edmonton, Alberta: 145-181.

Received 7 August 1995, accepted 18 June 1996. 